This is the peer reviewed version of the following article: Chemistry - A European Journal, 2010, Volume 16, Issue 46, Pages 13599-13602, which has been published in final form at: https://doi.org/10.1002/chem.201002482

\title{
Novel Synthetic Pathway for New Zn-Zn-Bonded Compounds from Dizincocene
}

\author{
Sebastian Gondzik, Dieter Bläser, Christoph Wölper, and Stephan Schulz*[a]
}

Dedicated to Prof. Dr. Dr. h.c. mult. Herbert W. Roesky on the occasion of his $75^{\text {th }}$ birthday.

[a] Prof. Dr. S. Schulz, Inorganic Chemistry, University of Duisburg-Essen, S07 S03 C30, 45117 Essen, Fax: (+) 201-1833830, E-mail: stephan.schulz@uni-due.de

Since the initial synthesis of decamethyldizincocene $\mathrm{Cp}^{*}{ }_{2} \mathrm{Zn}_{2},[1]$ the first stable molecular compound containing a direct $\mathrm{Zn}-\mathrm{Zn}$ bond with the $\mathrm{Zn}$ atoms in the formal oxidation state +1 ,[2] by Carmona et al. in 2004, an increasing number of $\mathrm{Zn}(\mathrm{I})$ complexes have been structurally characterized.[3] Most of these complexes, which are typically kinetically stabilized by sterically bulky, very often chelating organic ligands, have been synthesized by Wurtz-analogous coupling reaction of the corresponding halide-substituted complexes RZnX except for $\mathrm{Cp}_{2}{ }_{2} \mathrm{Zn}_{2}$, which was initially prepared by reaction of $\mathrm{Et}_{2} \mathrm{Zn}$ and $\mathrm{Cp}^{*} \mathrm{Zn}$. Unfortunately, coupling reactions very often tend to proceed with formation of the corresponding $\mathrm{Zn}$ (II) complexes and elemental zinc.[4] We therefore became interested in the development of alternate synthetic pathways. Very recently, we demonstrated that $\mathrm{Cp}^{*}{ }_{2} \mathrm{Zn}_{2}$ is a promising starting reagent for protonation reactions. While the reaction with $\left[\mathrm{H}\left(\mathrm{OEt}_{2}\right)\right]\left[\mathrm{Al}\left(\mathrm{OC}\left(\mathrm{CF}_{3}\right)_{3}\right)_{4}\right]_{2}$ yielded $\left[\mathrm{Zn}_{2}(\mathrm{dmap})_{6}\right]\left[\mathrm{Al}\left(\mathrm{OC}\left(\mathrm{CF}_{3}\right)_{3}\right)_{4}\right]_{2}$ containing the first basestabilized $\left[\mathrm{Zn}_{2}\right]^{2+}$ dication, $[5]$ the reaction with $\mathrm{N}-\mathrm{H}$ acidic $[\{(2,4,6-$ $\left.\left.\mathrm{Me}_{3} \mathrm{C}_{6} \mathrm{H}_{2}\right) \mathrm{N}(\mathrm{Me}) \mathrm{C}{ }_{2} \mathrm{CH}\right] \mathrm{H}$ (MesnacnacH) proceeded with elimination of $\mathrm{Cp}^{*} \mathrm{H}$ and subsequent formation of the $\mathrm{Zn}(\mathrm{I})$ complex Mesnacnac $\mathrm{Zn}_{2}$.[6] In addition, reactions with sterically demanding alcohols[7] and bis(iminodi(phenyl)phosphorano)methanes[8] also occurred with preservation of the $\mathrm{Zn}-\mathrm{Zn}$ bond and formation of the corresponding (basestabilized) $\mathrm{Zn}(\mathrm{I})$ alkoxides and $\mathrm{Zn}(\mathrm{I})$ bis(iminodi(phenyl)phosphorano)methanides, respectively. These protonation reactions can be performed at low temperature, hence also allowing the synthesis of thermally less stable $\mathrm{Zn}(\mathrm{I})$ complexes. In contrast, the reaction of Dipp-BIAN $\mathrm{Zn}_{2}$ with $\mathrm{C}$-H acidic phenylacetylene occurred with $\mathrm{H}_{2}$-elimination and formation of a binuclear acetylene bridged $\mathrm{Zn}$ (II) complex (redox reaction) rather than with protonation of the Dipp-BIAN substituent.[9]

We herein report on the reaction of dizincocene with the potassium salt of tris(3,5-

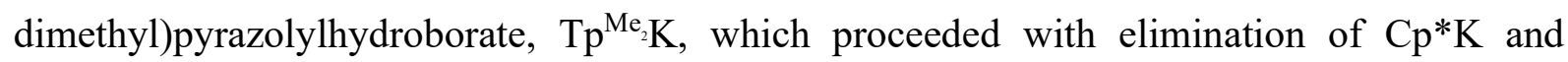
subsequent formation of $\left(\mathrm{Tp}^{\mathrm{Me}_{2}}\right) \mathrm{Zn}-\mathrm{Zn}\left(\mathrm{Tp}^{\mathrm{Me}_{2}}\right)_{2} \mathbf{1}$. In addition, zincocene $\mathrm{Cp}^{*}{ }_{2} \mathrm{Zn}$ was found to 
react analogously with two equivalents $\mathrm{KTp}^{\mathrm{Me}_{2}}$ with formation of $\left(\mathrm{Tp}^{\mathrm{Me}_{2}}\right)_{2} \mathrm{Zn} \quad \mathbf{2}$. 2 was prepared and structurally characterized for the first time by Parkin et al.[10]

2

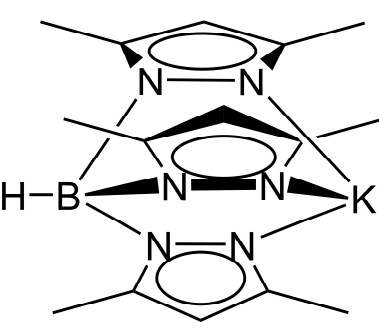

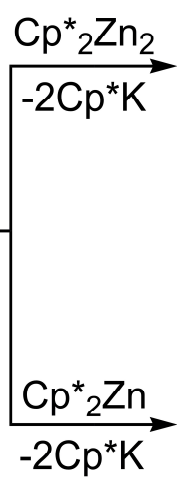
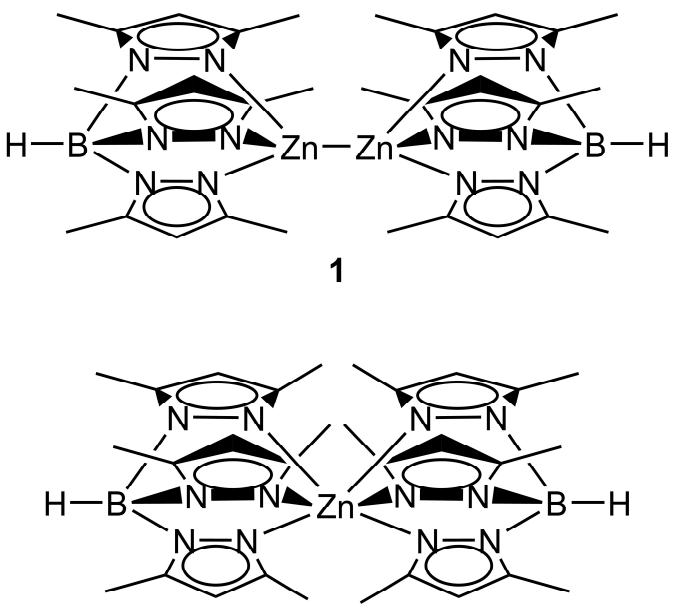

2

Scheme 1. Synthesis of pyrazolylhydroborate zinc complexes 1 and 2.

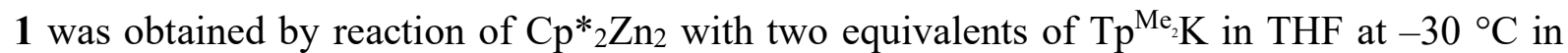
almost quantitative yield ( $>90 \%$ ), which is significantly higher compared to yields reported for $\mathrm{Zn}(\mathrm{I})$ complexes obtained from reduction reactions. The formation of elemental zinc (disproportionation reaction) was not observed. Zincocene $\mathrm{Cp}^{*}{ }_{2} \mathrm{Zn}$ reacts analogously with formation of $\left(\mathrm{Tp}^{\mathrm{Me}_{2}}\right)_{2} \mathrm{Zn} \mathbf{2} .1$ and $\mathbf{2}$ are soluble in organic solvents such as toluene and THF, respectively. ${ }^{1} \mathrm{H},{ }^{13} \mathrm{C}$ and ${ }^{11} \mathrm{~B}$ NMR spectra of both complexes show resonances due to the tris(pyrazolyl)hydroborato ligands. H-B resonances were not observed in the ${ }^{1} \mathrm{H}$ NMR spectra as is typical for these complexes,[10a] but the IR spectra of $\mathbf{1}$ and $\mathbf{2}$ show strong vibrational bands at 2506 (1) and 2512 (2), respectively. 1 is extremely thermally robust $\left(\mathrm{T}_{\text {decomp. }} 395{ }^{\circ} \mathrm{C}\right)$ compared to other $\mathrm{Zn}(\mathrm{I})$ complexes, most likely resulting from the steric shielding due to the pyrazolylhydroborate ligand and the high coordination number of the $\mathrm{Zn}$ atoms, which are tetrahedrally coordinated. A solution of $\mathbf{1}$ in organic solvents is stable for days, in contrast to $\mathrm{Cp}^{*}{ }_{2} \mathrm{Zn}_{2}$, that decomposes within a very few hours.

The solid-state structures of $\mathbf{1}$ (Fig. 1) and $\mathbf{2}$ (Fig. 2) were determined by single crystal X-ray diffraction.[11] Suitable crystals were obtained from solutions in $\mathrm{THF} / \mathrm{CH}_{2} \mathrm{Cl}_{2}$ (1) and $\mathrm{THF}$ (2) after slow crystallization at $+4{ }^{\circ} \mathrm{C} .1$ crystallizes in the monoclinic space group $P 2{ }_{1} / n$ together with three $\mathrm{CH}_{2} \mathrm{Cl}_{2}$ and one THF molecules, 2 in the trigonal space group $R \overline{3} c$. With $\mathrm{Zn}$ atoms on special positions, two independent molecules together with highly disordered THF molecules result from the asymmetric unit [12]. 


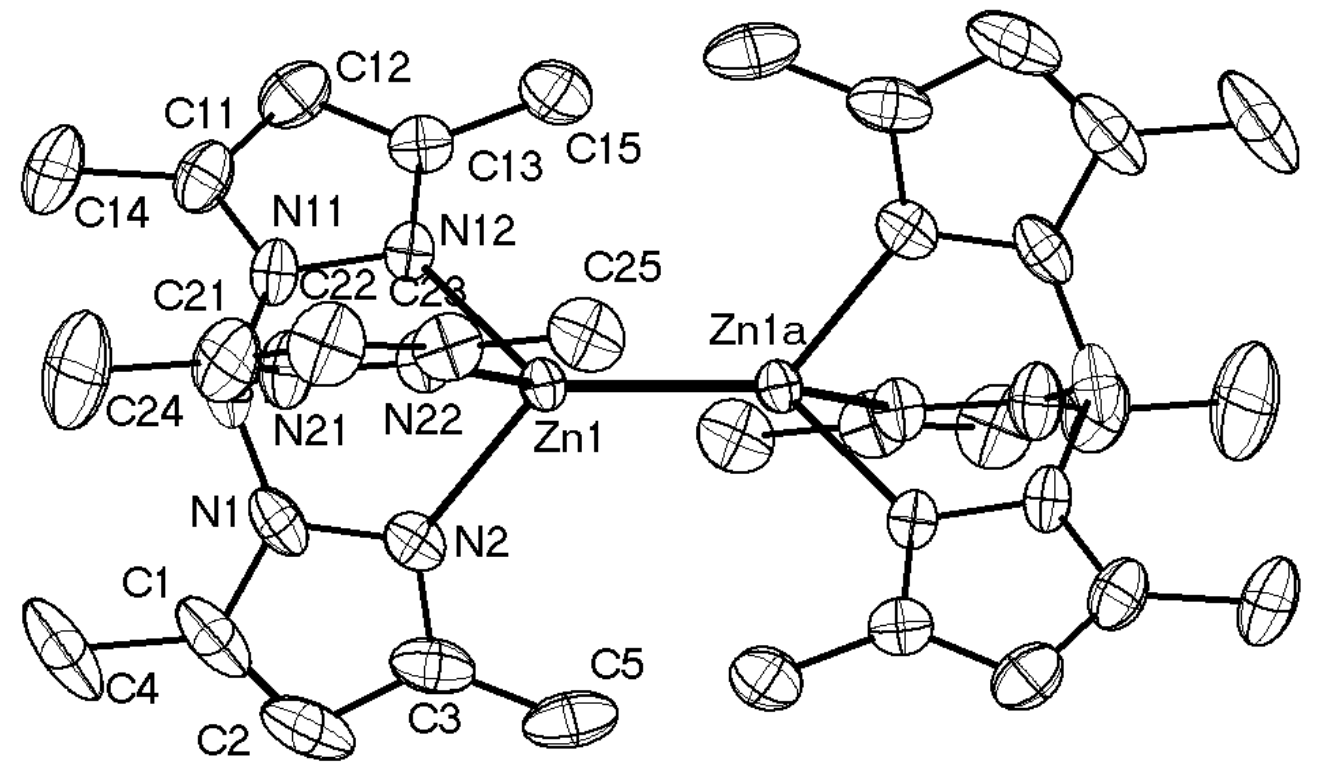

Figure 1. Solid state structure of 1; Znla and non-labeled atoms symmetry-equivalent via inversion $(-\mathrm{x}+1,-\mathrm{y},-\mathrm{z}+1)$, ellipsoids correspond to $50 \%$ probability levels; $\mathrm{H}$ atoms are omitted for clarity. Selected bond lengths $(\AA)$ and angles $\left(^{\circ}\right)$ : $Z n(1)-Z n(1) \# 12.3560(9), Z n(1)-N(2)$ 2.099(4), Zn(1)-N(22) 2.103(3), Zn(1)-N(12) 2.104(3), N(2)-Zn(1)-N(22) 88.02(14), N(2)Zn(1)-N(12) 87.98(14), N(22)-Zn(1)-N(12) 86.71(13), N(2)-Zn(1)-Zn(1)1a 126.27(11), $\mathrm{N}(22)-Z n(1)-Z n(1) 1 \mathrm{a} 126.12(10), \mathrm{N}(12)-Z n(1)-Z n(1) 1 \mathrm{a} 128.49(10)$.

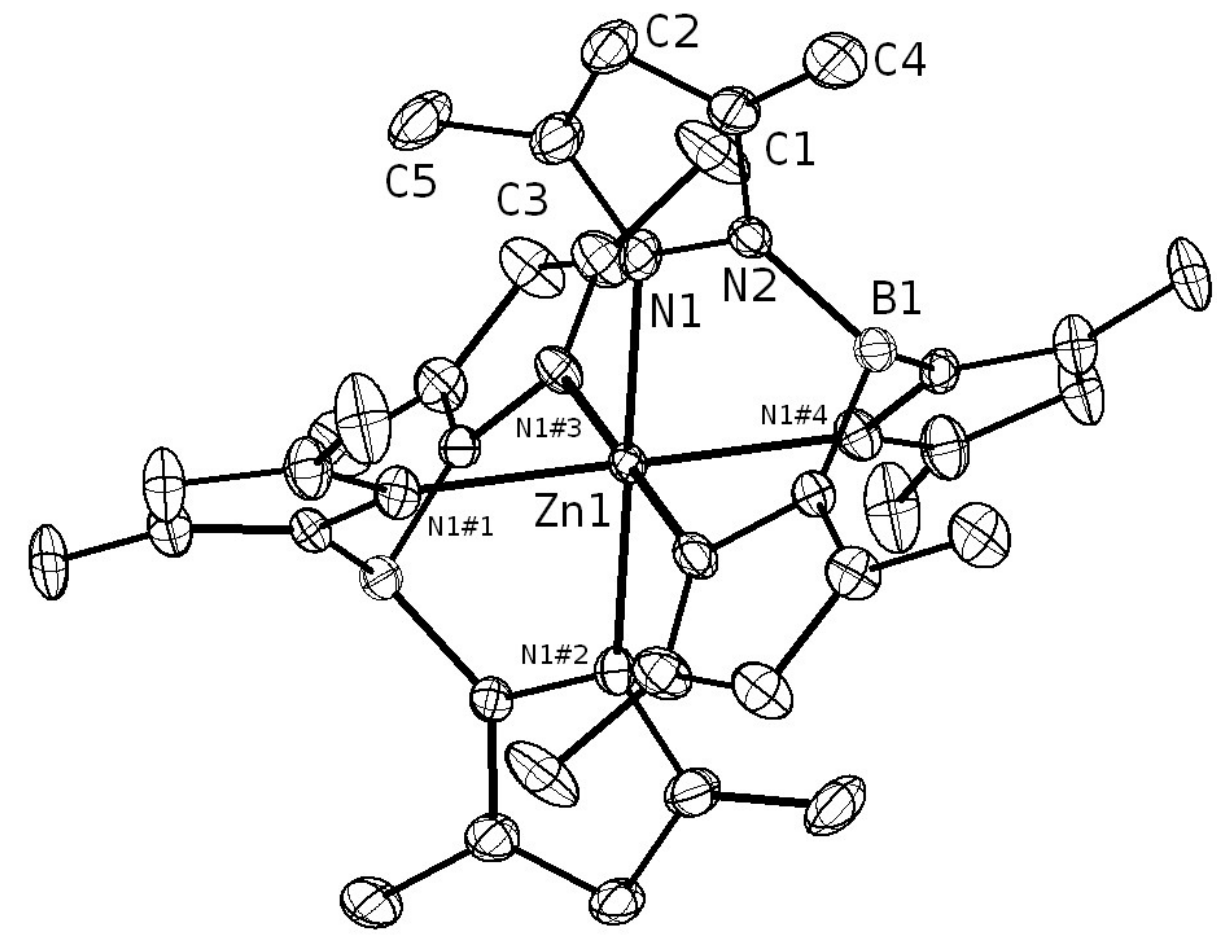

Figure 2. Solid state structure of 2; non-labeled atoms symmetry-equivalent via 32, ellipsoids correspond to $50 \%$ probability levels; $\mathrm{H}$ atoms are omitted for clarity; only one of two independent molecules is presented. Selected bond lengths $(\AA)$ and angles $\left(^{\circ}\right)$ : $\mathrm{Zn}(1)-\mathrm{N}(1)$ 
2.179(2), N(1)1a-Zn(1)-N(1) 94.59(11), N(1)\#2-Zn(1)-N(1) 179.74(12), N(1)\#3-Zn(1)-N(1) 94.23(11), N(1)\#4-Zn(1)-N(1) 85.59(8)[13].

The tris(pyrazolyl)hydroborato ligands in $\mathbf{1}$ and $\mathbf{2}$ bind in a $\eta^{3}$-coordination mode to the $\mathrm{Zn}$ atoms. As a consequence, the $\mathrm{Zn}$ atoms in $\mathbf{1}$ adopt tetrahedral coordination spheres, whereas that in $\mathbf{2}$ is almost perfect octahedrally coordinated by six $\mathrm{N}$ atoms. The $\mathrm{Zn}-\mathrm{N}$ bond lengths in 2 (2.179(2), 2.184(2) $\AA$ ) are comparable to those reported previously for this complex,[10] whereas those in 1 are significantly shorter (av. value 2.102(4) $\AA$ ). This finding clearly points to decreased sterical interactions between the two substituents in $\mathbf{1}$ compared to $\mathbf{2}$ due to the presence of the $\mathrm{Zn}_{2}$ unit. Both tris(pyrazolyl)hydroborato ligands in 1 adopt an almost perfect staggered orientation (torsions $58.15(17)^{\circ}, 61.16(18)^{\circ}$ ) to each other in order to further decrease sterical interactions. The bonding parameters (B-N, C-C, C-N bond lengths) of the tris(pyrazolyl)hydroborates in $\mathbf{1}$ and $\mathbf{2}$ are comparable and in the typical range as was observed for tris(pyrazolyl)hydroborate zinc complexes of the types $\left(\mathrm{Tp}^{\mathrm{Me}_{2}}\right)_{2} \mathrm{Zn}$ [10] and $\left(\mathrm{Tp}^{\mathrm{Me}_{2}}\right)_{2} \mathrm{ZnX}$.[14] The $\mathrm{Zn}-\mathrm{Zn}$ bond length in $\mathbf{1}$ of 2.3560(9) $\AA$ is elongated compared to that observed for $\mathrm{Cp}^{*}{ }_{2} \mathrm{Zn}_{2}(2.305(3) \AA),[1]$ but comparable to those reported for the homoleptic $\mathrm{Zn}(\mathrm{I})$ complexes $\left[\mathrm{CH}_{2}\left(\mathrm{Ph}_{2} \mathrm{P}=\mathrm{NPh}\right)_{2}\right]_{2} \mathrm{Zn}_{2}(2.3490(1) \AA)[8]$ and Dippnacnac $2 \mathrm{Zn}_{2}(2.3586(7) \AA)$ containing $\mathrm{N}, \mathrm{N}^{\prime}$ chelating-ligands.[3b] In contrast, the $\mathrm{Zn}-\mathrm{Zn}$ bond in Mesnacnac $2 \mathrm{Zn}_{2}$ (2.3813(8) $\AA)$ is slightly elongated.[6]

Conclusion. The $\mathrm{Cp}^{*}$ ligands in $\mathrm{Cp}^{*}{ }_{2} \mathrm{Zn}_{2}$ can easily be replaced by tris(pyrazolyl)hydroborato ligands by reaction with the corresponding potassium salt under mild reaction conditions. This new reaction type may give access to a larger number of $\mathrm{Zn}(\mathrm{I})$ complexes in the near future including complexes, which cannot be obtained from Wurtz-analogous reductions reactions. We are currently investigating reactions with potassium salts of different types of organic substituents as well as with their corresponding Li salts, which would greatly increase the applicability of the reaction type for the synthesis of novel $\mathrm{Zn}-\mathrm{Zn}$-bonded complexes.

\section{Experimental Section}

All manipulations were performed in a glovebox under an Ar-atmosphere or with standard Schlenk techniques. Solvents were dried by standard procedures and degassed prior to use. $\mathrm{Cp}^{*}{ }_{2} \mathrm{Zn}[15]$ and $\mathrm{Cp}^{*}{ }_{2} \mathrm{Zn}_{2}[1 \mathrm{~b}]$ were prepared according to literature methods, tris $(3,5-$

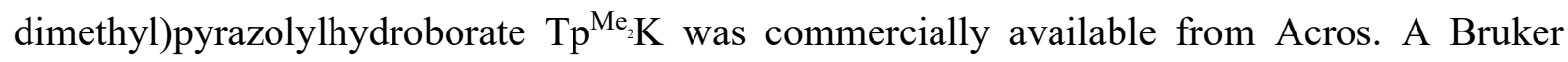
Avance 500 spectrometer was used for NMR spectroscopy. ${ }^{1} \mathrm{H}$ and ${ }^{13} \mathrm{C}\left\{{ }^{1} \mathrm{H}\right\}$ NMR spectra were referenced to internal THF-d $8\left({ }^{1} \mathrm{H}: \delta=3.58 ;{ }^{13} \mathrm{C}: \delta=67.4\right)$. IR spectra were recorded on an Alpha-T FT-IR spectrometer with a single reflection ATR sampling module. Melting points were measured in sealed capillaries and were not corrected. 
$Z n_{2}[3,5-M e-p z]_{2}$ (1). $0.32 \mathrm{~g}(1.00 \mathrm{mmol})$ of $\mathrm{Tp}^{\mathrm{Me}} \mathrm{K}$ and $0.20 \mathrm{~g}(0.50 \mathrm{mmol})$ of $\mathrm{Cp}^{*}{ }_{2} \mathrm{Zn}_{2}$ were suspended in $50 \mathrm{~mL}$ of THF at $-30{ }^{\circ} \mathrm{C}$ and stirred for $6 \mathrm{~h}$. The white precipitate was filtered and the solution concentrated in vacuum. $\mathrm{CH}_{2} \mathrm{Cl}_{2}$ was added and the resulting solution was stored at $+4{ }^{\circ} \mathrm{C}$ for $24 \mathrm{~h}$, yielding 1 as colorless crystals.

Yield 0.1 g (93.6 \%); m.p. $395{ }^{\circ} \mathrm{C}$ (decomp.); IR: $v=2962,2923,2506$ (B-H), 1543, 1446, $1417,1385,1350,1258,1194,1181,1057,1013,850,784,694,642,460,391 \mathrm{~cm}^{-1} ;{ }^{1} \mathrm{H}$ NMR $\left(300 \mathrm{MHz},[\mathrm{D} 8] \mathrm{THF}, 25^{\circ} \mathrm{C}\right): \delta=2.35$ (s, 9H, CMe), $2.37(\mathrm{~s}, 9 \mathrm{H}, \mathrm{CMe}), 5.66(\mathrm{~s}, 3 \mathrm{H}, \mathrm{CH}) ;{ }^{13} \mathrm{C}$ NMR (300 MHz, [D8]THF, $\left.25^{\circ} \mathrm{C}\right): \delta=12.4\left(\mathrm{CH}_{3}\right), 13.9\left(\mathrm{CH}_{3}\right), 105.1(\mathrm{CC}(\mathrm{H}) \mathrm{C}), 144.1$ $(C \mathrm{C}(\mathrm{H}) \mathrm{C}), 148.9(\mathrm{CC}(\mathrm{H}) C) ;{ }^{11} \mathrm{~B}$ NMR $\left(300 \mathrm{MHz},[\mathrm{D} 8] \mathrm{THF}, 25^{\circ} \mathrm{C}\right): \delta=-9.6(B \mathrm{H})$.

$Z n[3,5-M e-p z]_{2}$ (2). $0.64 \mathrm{~g}(2.00 \mathrm{mmol})$ of $\mathrm{Tp}^{\mathrm{Me}} \mathrm{K}$ and $0.32 \mathrm{~g}(1.00 \mathrm{mmol})$ of $\mathrm{Cp}^{*}{ }_{2} \mathrm{Zn}$ were suspended at room temperature in $50 \mathrm{~mL}$ of $n$-pentane and stirred for $12 \mathrm{~h}$. The white precipitate was filtered and the solvent removed in vacuum, yielding a white yellowish solid. The solid was dissolved in THF and stored at $+4{ }^{\circ} \mathrm{C}$. Colorless crystals of 2 formed after $24 \mathrm{~h}$. Yield 0.25 g (89.3 \%); IR: $v=2962,2924,2512$ (B-H), 1538, 1443, 1414, 1380, 1364, 1351, 1259, 1201, 1186, 1061, 1038, 841, 800, 766, 695, 644, 460, $392 \mathrm{~cm}^{-1}$; ${ }^{1} \mathrm{H}$ NMR $(300 \mathrm{MHz}$, [D8]THF, $\left.25^{\circ} \mathrm{C}\right): \delta=1.34(\mathrm{~s}, 9 \mathrm{H}, \mathrm{CMe}), 2.41(\mathrm{~s}, 9 \mathrm{H}, \mathrm{CMe}), 5.58(\mathrm{~s}, 3 \mathrm{H}, \mathrm{CH}) ;{ }^{13} \mathrm{C} \mathrm{NMR}(300$ $\left.\mathrm{MHz},[\mathrm{D} 8] \mathrm{THF}, 25^{\circ} \mathrm{C}\right): \delta=12.0\left(\mathrm{CH}_{3}\right), 12.8\left(\mathrm{CH}_{3}\right), 105.3(\mathrm{CC}(\mathrm{H}) \mathrm{C}), 143.6(\mathrm{CC}(\mathrm{H}) \mathrm{C}), 149.2$ $(\mathrm{CC}(\mathrm{H}) C) ;{ }^{11} \mathrm{~B}$ NMR $\left(300 \mathrm{MHz},[\mathrm{D} 8] \mathrm{THF}, 25^{\circ} \mathrm{C}\right): \delta=-9.5(B \mathrm{H})$.

Single Crystal Structure Determination of 1 and 2. The crystals were mounted on nylon loops in inert oil. Data were collected on a Bruker D8 Kappa diffractometer with APEX2detector (monochromated $\mathrm{MoK}_{\alpha}$ radiation, $\lambda=0.71073 \AA$ ) at $100 \mathrm{~K}$. The structures were solved by Direct Methods using Bruker AXS APEX 2 software [16] and refined by full-matrix least-squares on $F^{2}$. Semi-empirical absorption corrections were applied (SADABS). All nonhydrogen atoms were refined anisotropically and hydrogen atoms by a riding model (SHELXL97, Program for Crystal Structure Refinement).[17] The refinement of 1 was performed with solvent-free reflection data following Platon/SQueEze[18] run. A refinement of the untreated reflection data set produces ten peaks with $1.5-2.1 \mathrm{e} / \AA^{3}$ corresponding to two highly disordered THF molecules with point symmetrie $\overline{1}$. The ten highest peaks in the difference Fourier map were attributed to carbon atoms. This attempt resulted in $\mathrm{R} 1=0.1270$. The SQUEEZE refinement revealed voids with total volume of $4436 \AA^{3}$ at the positions 0.026 , $0.474,-0.026$ and $-0.076,0.212,0.212$ and $0.125,0.751,0.375$ corresponding to $1479 \AA^{3}$ each. 2 contained disordered solvent: one molecule of THF and dichloromethane at the same site with SOF 0.5 each. The THF atoms $[\mathrm{O}(40), \mathrm{C}(41-44)]$ were refined with fixed $\mathrm{U}=0.08$. 
The chlorine atoms of the dichloromethan $[\mathrm{Cl}(3,4)]$ were refined anisotropic while the carbon $[\mathrm{C}(31)]$ was refined isotropically.

CCDC-790372 (1) and -790371 (2) contain the supplementary crystallographic data for this paper. These data can be obtained free of charge from The Cambridge Crystallographic Data Centre via www.ccdc.cam.ac.uk/data_request/cif.

\section{Acknowledgements}

Financial support from the Deutsche Forschungsgemeinschaft DFG (grant no SCHU 1069/131) is gratefully acknowledged.

\section{Entry for the Table of Contents}

Layout 2:

Phrase: Making new from existing

Sebastian Gondzik, Dieter Bläser, Roland Boese, and Stephan Schulz*

Novel Synthetic Pathway for New Zn-Zn-Bonded Compounds from Dizincocene

\section{References}

[1] a) I. Resa, E. Carmona, E. Gutierrez-Puebla, Á. Monge, Science 2004, 305, 1136-1138; b) D. del Río, A. Galindo, I. Resa, E. Carmona, Angew. Chem. 2005, 117, 1270-1273; Angew. Chem. Int. Ed. 2005, 44, 1244-1247; c) J. F. van der Maelen, E. Gutiérrez-Puebla, Á. Monge. S. García-Granda, I. Resa, E. Carmona, M. T. Fernández-Díaz, G. J. McIntyre, P. Pattison, H.-P. Weber, Acta. Cryst. 2007, B63, 862-868. For review article see: a) E. Carmona, A. Galindo, Angew. Chem. 2008, 120, 6626-6637; Angew. Chem. Int. Ed. 2008, 47, 6526-6537; b) D. L. Kays, S. Aldridge, Angew. Chem. 2009, 121, 4172-4174; Angew. Chem. Int. Ed. 2009, 48, 4109-4111.

[2] $\mathrm{Zn}_{2} \mathrm{H}_{2}$ has been previously trapped in an Ar matrix at $12 \mathrm{~K}$ and characterized by vibrational spectroscopy and theoretical calculations. X. Wang, L. Andrews, J. Phys. Chem. A 2004, 108, 11006-11013; T. M. Greene, W. Brown, L. Andrews, A. J. Downs, G. V. Chertihin, N. Runeberg, P. Pyykkö, J. Phys. Chem. 1995, 99, 7925-7934.

[3] a) A. Grirrane, I. Resa, A.; Rodriguez, E. Carmona, E. Alvarez, E. Gutierrez-Puebla, Á. Monge, A. Galindo, D. del Río, R. A. Andersen, J. Am. Chem. Soc. 2007, 129, 693-703; b) Y. Wang, B. Quillian, P. Wei, H. Wang, X.-J. Yang, Y. Xie, R. B. King, P. v. R. Schleyer, H. F. Schaefer III, G. H. Robinson, J. Am. Chem. Soc. 2005, 127, 11944-11945; c) Z. Zhu, R. J. Wright, M. M. Olmstead, E. Rivard, M. Brynda, P. P. Power, Angew. Chem. 2006, 118, 59395942; Angew. Chem. Int. Ed. 2006, 45, 5807-5810; d) Z. Zhu, M. Brynda, R. J. Wright, R. C. 
Fischer, W. A. Merrill, E. Rivard, R. Wolf, J. C. Fettinger, M. M. Olmstead, P. P. Power, J. Am. Chem. Soc. 2007, 129, 10847-10857; e) X.-J. Yang, J. Yu, Y. Liu, Y. Xie, H. F. Schaefer III, Y. Liang, B. Wu, Chem. Commun. 2007, 2363-2365; Y.-C. Tsai, D.-Y. Lu, Y.-M. Lin, J.K. Hwang, J.-S. K. Yu, Chem. Commun. 2007, 4125-4127; f) I. L. Fedushkin, A. A. Skatova, S. Y. Ketkov, O. V. Eremenko, A. V. Piskunov, G. K. Fukin, Angew. Chem. 2007, 119, 43804383; Angew. Chem. Int. Ed. 2007, 46, 4302-4305; g) J. Yu, X.-J. Yang, Y. Liu, Z. Pu, Q.-S. Li, Y. Xie, H. F. Schaefer, B. Wu, Organometallics 2008, 27, 5800-5805; h) P. Yang, X.-J. Yang, J. Yu, Y. Liu, C. Zhang, Y.-H. Deng, B. Wu, Dalton Trans. 2009, 5773-5779: i) Y. Liu, S. Li, X.-J. Yang, P. Yang, J. Gao, Y. Xia, B. Wu, Organometallics 2009, 28, 52705272.

[4] S. Schulz, T. Eisenmann, D. Bläser, R. Boese, Z. Anorg. Allg. Chem. 2009, 635, 995-1000.

[5] S. Schulz, D. Schuchmann, I. Krossing, D. Himmel, D. Bläser, R. Boese, Angew. Chem. 2009, 121, 5859-5862; Angew. Chem. Int. Ed. 2009, 48, 5748-5751.

[6] S. Schulz, D. Schuchmann, U. Westphal, M. Bolte, Organometallics 2009, 28, 1590-1592.

[7] M. Carrasco, R. Peloso, A. Rodríguez, E Álvarez, C Maya, E. Carmona, Chem. Eur. J. 2010, 16, 9754-9757.

[8] S. Schulz, S. Gondzik, D. Schuchmann, U. Westphal, L. Dobrzycki, R. Boese, S. Harder, Chem. Commun., DOI:10.1039/C0CC02859B.

[9] I. L. Fedushkin, O. V. Eremenko, A. A. Skatova, A. V. Piskunov, G. K. Fukin, S. Y. Ketkov, E. Irran, H. Schumann, Organometallics 2009, 28, 3863-3868.

[10] a) A. Looney, R. Han, I. B. Gorrell, M. Cornebise, K. Yoon, G. Parkin, A. L. Rheingold, Organometallics 1995, 14, 274-288; b) K.-W. Yang, Y.-Z. Wang, Z.-X. Huang, J. Sun, Polyhedron 1997, 16, 1297-1300.

[11] Crystal data for 1: $\mathrm{C}_{30} \mathrm{H}_{28} \mathrm{~N}_{12} \mathrm{~B}_{2} \mathrm{Zn}_{2} * 3\left[\mathrm{CH}_{2} \mathrm{Cl}_{2}\right] * \mathrm{C}_{4} \mathrm{H}_{8} \mathrm{O}, M=1052.01$, colorless crystal $(0.27 \times 0.22 \times 0.15 \mathrm{~mm})$; monoclinic, space group $P 2{ }_{1} / n ; a=7.9280(4), b=27.6966(13), c=$ 11.5109(5) $\AA ; \beta=103.231(2)^{\circ}, V=2460.5(2) \AA^{3} ; Z=2 ; \mu=1.34 \mathrm{~mm}^{-1} ; \rho_{\text {ber. }}=1.420 \mathrm{~g} \mathrm{~cm}^{-3}$; 22749 reflexes $\left(2 \theta_{\max }=49.6^{\circ}\right), 4250$ unique $\left(R_{\text {int }}=0.0272\right) ; 276$ parameters; largest max./min. in the final difference Fourier synthesis 1.024/-1.391 $\AA^{-3}$; max./min. transmission $0.75 / 0.56 ; R_{1}=0.0586(I>2 \sigma(I)), w R_{2}$ (all data) $=0.1485$. Crystal data for 2: $\mathrm{C}_{30} \mathrm{H}_{44} \mathrm{~B}_{2} \mathrm{~N}_{12} \mathrm{Zn} * \mathrm{THF}, M=659.76$, colorless crystal $(0.28 \times 0.23 \times 0.16 \mathrm{~mm})$; trigonal, space group $R \overline{3} c ; a=17.1545(8), b=17.1545(8), c=52.772(3) \AA \AA \alpha=\beta=90^{\circ}, \gamma=120^{\circ}, V=$ 13449.1(11) $\AA^{3} ; Z=12 ; \mu=1.63 \mathrm{~mm}^{-1} ; \rho_{\text {ber. }}=1.324 \mathrm{~g} \mathrm{~cm}^{-3} ; 45486$ reflexes $\left(2 \theta_{\max }=56.6^{\circ}\right)$, 3673 unique $\left(R_{\text {int }}=0.0286\right) ; 137$ parameters; largest max./min. in the final difference Fourier 
synthesis $0.616 /-0.459 \mathrm{e}^{-3}$; max./min. transmission $0.75 / 0.59 ; R_{1}=0.0640(I>2 \sigma(I)), w R_{2}$ $($ all data $)=0.1399$.

[12] The $\mathrm{Zn}$ atoms are located on special positions $(\mathrm{Zn}(1)$ on $32, \mathrm{Zn}(2)$ on $\overline{3})$. The asymmetric unit contains one sixth of each molecule [as labeled in Fig. 2 for $\mathrm{Zn}(1)$ ] and apparently two, highly disordered molecules of THF with SOF $\sim 0.5$ (treated with SQUEEZE). Consequently, the ratio $\mathrm{Zn}$ complex to THF is approx. 1:3.

[13] Bond angles for the second independent molecule: $\mathrm{N}(21)-\mathrm{Zn}(2)-\mathrm{N}(21) \# 5$ 180.0; $\mathrm{N}(21)-$ $\mathrm{Zn}(2)-\mathrm{N}(21) \# 6 \quad 94.20(8), \quad \mathrm{N}(21)-\mathrm{Zn}(2)-\mathrm{N}(21) \# 7 \quad 85.80(8) \quad$ Symmetry operations for equivalents: \#1 x-y+1/3,-y+2/3,-z+1/6; \#2 -x+4/3,-x+y+2/3,-z+1/6; \#3 y+1/3,x-1/3,-z+1/6; \#4 -y+1,x-y,z; \#5 -x,-y,-z; \#6 y,-x+y,-z; \#7 -y,x-y,z.

[14] See the following reviews and references cited therein: a) S. Trofimenko in Scorpionates: The Coordination Chemistry of Polypyrazolylborate Ligands, 1999, Imperial College Press, London; b) C. Pettinari, C. Santini in Comprehensive Coordination Chemistry II 2004, 1, 159-210; c) G. Parkin, Chem. Rev. 2004, 104, 699-767.

[15] R. Blom, J. Boersma, P. H. M. Budzelaar, B. Fischer, A. Haaland, H. V. Volden, J. Weidlein, Acta Chem. Scand. 1986, A 40, 113.

[16] Bruker AXS APEX 2 Vers.3.0/2009.

[17] G. M. Sheldrick, SHELXL-97, Program for the Refinement of Crystal Structures University of Göttingen, Göttingen (Germany) 1997, siehe auch: G. M. Sheldrick, Acta Cryst., 2008, A64, 112-122.

[18] A. L. Spek, Acta Cryst.1990, A46, C-34.

Keywords: Zinc $\bullet$ Metal-metal interaction $\bullet$ N ligands $\bullet$ X-ray diffraction 


\section{DuEPublico}

Duisburg-Essen Publications online

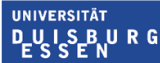

offen im Denken

Ub $\mid \begin{aligned} & \text { universitäts } \\ & \text { bibliothek }\end{aligned}$

This text is made available via DuEPublico, the institutional repository of the University of Duisburg-Essen. This version may eventually differ from another version distributed by a commercial publisher.

\section{DOI: $\quad$ 10.1002/chem.201002482}

URN: urn:nbn:de:hbz:464-20201104-103723-3

This is the peer reviewed version of the following article: Chemistry - A European Journal, 2010, Volume 16, Issue 46, Pages 13599-13602, which has been published in final form at: https://doi.org/10.1002/chem.201002482

All rights reserved. 